\title{
Influence of Different Curing Conditions on Density and Compressive Strength of Hardened Concrete with Various Types of Chemical Admixtures
}

\section{Gintas Brazas, Mindaugas Daukšys*, Albertas Klovas, Jolanta Šadauskienė}

Kaunas University of Technology, Faculty of Civil Engineering and Architecture

Studentu str. 48, LT-51367 Kaunas, Lithuania

${ }^{*}$ Corresponding author: mindaugas.dauksys@ktu.lt

\section{$\Gamma$} crossef http://dx.doi.org/10.5755/j01.sace.14.1.14479

The research was made in order to determine the influence of the standard and non-standard curing conditions on the density and compressive strength of concrete specimens, when the mixture of concrete was modified by the use of different admixtures. From the same concrete mixture, part of the formed concrete specimens were cured according to the standard, another part - according to non-standard method. According to the requirements of the EN 12390-2:2009 standard, the specimens were cured for 28 days in water at the temperature of $20 \pm 2^{\circ} \mathrm{C}$. Another part of the specimens, which were covered by polyethylene covering, were cured for 28 days in a room with the temperature of $20 \pm 4^{\circ} \mathrm{C}$ and relative humidity of $60 \pm 2 \%$. After that, comparison of density and compressive strength values of specimens, cured in different conditions, was made. It was found, that the density of specimens cured by standard way was higher than the density of specimens which were cured in non-standard way, chemical admixture type did not influence the results. The trends of compressive strength of concrete specimens, cured by different methods, depended on the type and percentage of chemical admixture in the mass of cement.

KEYWORDS: curing conditions, chemical admixture, hardened concrete, density, compressive strength.

Nowadays, the concrete admixtures are widely used in the construction projects. Various types of chemical admixtures are used to improve concrete's construction properties: workability, pumpability, setting properties, the mechanical performance, the durability (such as freeze thaw resistance and the shrinkage properties) and others (such as corrosion inhibitors and colouring agents etc.) (Plank et al. 2015; Albayraka et al. 2015; Lazniewska-Piekarczyka, 2013). The structure of hydration products generated during the cement's hydration, as well as the use of different concrete admixtures have influence on the formation of concrete structure during the solidification process.

Atis, 2005 investigated the strength properties of high-volume fly ash (HVFA) roller compacted and superplasticized workable concrete cured at moist and dry curing conditions. Concrete mixtures made with 0\%,50\% and 70\% replacement of normal Portland cement (NPC) with two dif-

\section{Introduction}

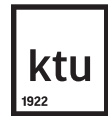

Journal of Sustainable Architecture and Civil Engineering Vol. 1 / No. 14 / 2016 pp. 31-43

DOI 10.5755/j01.sace.14.1.14479 (c) Kaunas University of Technology 
ferent low-lime Class F fly ashes were prepared. Water-cementious material ratios ranged from 0.28 to 0.43 . The influence of moist and dry curing conditions on the high-volume fly ash (HVFA) concrete system was assessed through a proposed simple efficiency factor. The study showed, that producing high-strength concrete was possible with high-volume fly ash content. Loss on ignition (LOI) content increased the water demand of fresh concrete. HVFA concrete was found to be more vulnerable to dry curing conditions than was NPC concrete.

Zhao et al. 2012 studied the effect of initial water-curing period and curing condition on properties of self-compacting concrete (SCC). Six different curing regimes were applied to the specimens, the first of which the specimen was stored under initial water-curing periods of 3, 7, 14 days, in the remaining three regimes, the specimens were continuous full water (FW) curing condition, continuous full standard (FS) curing condition and continuous full room (FR) curing condition. The mechanical properties of SCC under different initial water-curing period and curing condition were tested. The test results showed that it is necessary to apply water-curing to SCC for the initial 7 days period to expose the pozzolanic activity, SCC under FR curing condition has a higher compressive strength, flexural strength, a lower carbonation depth and chloride ion diffusion coefficient than SCC under FS, FW curing condition.

Tan and Gjorv, 1996 studied the effect of curing conditions on strength and permeability of concrete. Test results showed that after 3 and 7 days moist curing only the concretes with $\mathrm{w} / \mathrm{c}$ ratios equal to or less than 0.4 were accepted, while after 28 days of moist curing however, even the concrete with $w / c$ of 0.6 could be accepted. Silica fume has a significant effect on the resistance to water penetration. For the concretes both with and without silica fume and with $\mathrm{w} / \mathrm{c}+\mathrm{s}$ of 0.5 , the 28-day compressive strengths of 3 and 7 days moist curing were higher than those of 28 days moist curing, and the silica fume concrete seemed to be less sensitive to early drying. The curing temperatures did not affect the water penetration of concrete, but affected the chloride penetration and compressive strength of concrete significantly.

Ling and Teo, 2011 investigated the engineering properties of the bricks. Among the studied properties were: hardened concrete density, compressive strength and water absorption of the expanded polystyrene (EPS) rice husk ash (RHA) concrete bricks. Four types of curing conditions were employed in this study: full water curing, air dry curing, 3-day curing and 7-day curing. It was found that the properties of the bricks are mainly influenced by the curing condition used. Full water curing was the most effective method of curing. It produced the highest level of compressive strength and the lowest value of water absorption. On the contrary, air-dry curing produced the lowest level of compressive strength and the highest level of water absorption.

Gayarre et al. 2014 investigated the influence of different curing conditions on the compressive strength of recycled aggregate concrete. The concrete specimens were exposed to two different environments (standard curing and open-air curing) for 28 days. The results showed that the 7 -days strength increases with the percentage of replacement, being this behaviour more evident for the standard curing environment. The 28-days compressive strengths of concretes with recycled aggregates were found similar to the ones obtained with natural aggregate when the standard curing environment was considered. However, the recycled aggregate concrete specimens lost up to the $20 \%$ of their compressive strength when they were cured in open-air conditions.

Ling et al. 2012 studied the performance of self-compacting glass concrete (SCGC) after exposure to four elevated temperatures of $300^{\circ} \mathrm{C}, 500^{\circ} \mathrm{C}, 600^{\circ} \mathrm{C}$ and $800^{\circ} \mathrm{C}$. The influence of curing condition on the high temperature performance of SCGC was also investigated. The test results indicate that regardless of the exposure temperature, all the water cured specimens had higher residual strengths and mass losses while the water porosity and water sorptivity values were lower as compared to the corresponding air cured specimens.

Atis et al. 2005 studied compressive strength of silica fume concrete under dry and wet curing 
conditions. Three cubic specimens produced from fresh concrete were demoulded after a day; then, they were cured at $20 \pm 2{ }^{\circ} \mathrm{C}$ with $65 \%$ relative humidity $(\mathrm{RH})$, and three other cubic specimens were cured at $20 \pm 2{ }^{\circ} \mathrm{C}$ with $100 \% \mathrm{RH}$ until the specimens were used for compressive strength measurement at 28 days. The comparison was made on the basis of compressive strength between silica fume concrete and control Portland cement concrete. The comparisons showed that compressive strength of silica fume concrete cured at $65 \% \mathrm{RH}$ was influenced more than that of Portland cement concrete. It was found that the compressive strength of silica fume concrete cured at $65 \% \mathrm{RH}$ was, at average, 13\% lower than that of silica fume concrete cured at 100\% RH. The increase in the water-cementitious material ratios makes the concrete more sensitive to dry curing conditions. The influence of dry curing conditions on silica fume concrete was marked as the replacement ratio of silica fume increased.

The strength development and durability of concretes with silica fume (SF) and blast furnace slag (BFS) are reported to be critically dependent on the extent of curing and curing conditions (Turkmen, 2003). The specimens were cured in different curing regimes for periods varying from 28 , 75,150 , to 400 days before exposure to the experiments. It was observed that the specimens with SF\%10 + BFS\%20 and 0.35 water-binder ratios had the highest compressive strength and ultrasonic pulse velocity (UPV), the lowest capillarity coefficient and the appearing porosity. As a result, it can be concluded that the mineral admixtures improved the compressive strength, UPV, capillarity coefficient and appearing porosity.

Khatib and Mangat, 1999 examine the influence of one type of SP on porosity and pore size distribution under different curing regimes. Paste specimens with and without SP were prepared at constant water to cement ratio of 0.45 . Specimens were cured for 28 days and some for six months. Specimens were exposed to high temperature $\left(45^{\circ} \mathrm{C}\right)$ and normal temperature curing

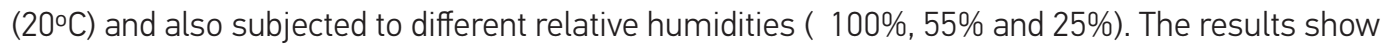
that the inclusion of SP decreases the total intruded pore volume of paste. The dominant pore diameter, however, does not seem to be affected and the percentage of pores smaller than $100 \mathrm{~nm}$ increases in the presence of SP.

According to authors (Ali et al. 2013) when the polycarboxylate-type admixture and the cement were compatible, the early strength was dependent on the type of admixture whereas at the ages beyond 7 days the strength became independent of the admixture type. The admixture causing the highest slump loss caused the highest concrete strength at early ages.

The mortars containing VMA developed $6 \%$ to 16\% lower compressive strength than those without any VMA (Saric-Coric et al. 2003). However, the compressive strength of mixtures made with polymelamine sulfonate (PMS) was higher that corresponding mixtures made with polynaphtalene sulfonate (PNS). This was partially due to the lower capillary porosity. Also, the C-S-H gel structure was more dense and compact in cement paste made without any VMA, indicating more advanced cement hydration that in the case of VMA mixtures where the structure was rather heterogeneous.

The type of SP is very important because of the parameters size of HPSCC air pores (Łazniewska-Piekarczyk, 2013). In case of HPSCC with "air-entraining" SP, the content of the air pores is higher only by $1.46 \%$, but the specific surface of the air voids, air voids spacing factor and content of the air voids with diameters less than $300 \mu \mathrm{m}$ are much higher. The type of AEA is very important due to the efficiency. The analysis of the results shows that the type of AEA significantly affects the total air content in hardened HPSCC. Other parameters of HPSCC porosity, with different types of AEA, are similar. However, depending on AFA type, more or less frequently there are the smallest air voids.

According to the standard curing method, specimens were cured for 28 days in water of temperature $20 \pm 2{ }^{\circ} \mathrm{C}$, after they were removed from the forms. Later on, certain designed values are deter- 
mined. During the construction process, on the building site, when monolithic concrete structures are made (for example, monolithic slabs), concrete surfaces are covered by certain materials (for example, polyethylene covering) during the curing process. This is done in order to lower the process of moisture remove from the concrete. Outside temperature, relative humidity and other factors are also influencing the curing process. In this study, from the same concrete mixture, part of the formed concrete specimens were cured according to the standard, another part according to non-standard method (when concrete specimens, covered by polyethylene covering, were cured for 28 days in a room). Later on, comparison of density and compressive strength values of specimens cured in different conditions was made.

The aim of this work is to determine influence of standard and non-standard curing conditions on the density and compressive strength of concrete specimens, when the mixture of concrete is modified by the use of different admixtures.

\begin{tabular}{|c|c|c|}
\hline \multirow{7}{*}{ Methods } & Specific surface area, $\mathrm{m}^{2} / \mathrm{kg}$ & \multirow{2}{*}{$\begin{array}{c}410 \\
3110\end{array}$} \\
\hline & Particle density, $\mathrm{kg} / \mathrm{m}^{3}$ & \\
\hline & Dry bulk density, $\mathrm{kg} / \mathrm{m}^{3}$ & 1220 \\
\hline & Water demand for normal consistency (by Vicat), \% & 26,5 \\
\hline & Volume stability, mm & 0,8 \\
\hline & Initial setting time, min. & 195 \\
\hline & Compressive strength after 2 days / after 28 days, $\mathrm{MPa}$ & $27.1 / 54.0$ \\
\hline Table 1 & Loss on ignition, \% (masès) & 5.05 \\
\hline \multirow{4}{*}{$\begin{array}{r}\text { Physical, mechanical } \\
\text { properties } \\
\text { and chemical } \\
\text { composition of } \\
\text { Portland cement } \\
\text { CEM II/A-LL } 42.5 \mathrm{R} \\
\text { (MA) (A) }\end{array}$} & Insoluble materials, \% (masės) & - \\
\hline & $\mathrm{SO}_{3}, \%$ & 2.48 \\
\hline & $\mathrm{Cl}^{-}, \%$ & 0.015 \\
\hline & Alkalis, calculated by $\mathrm{Na}_{2} \mathrm{O}$ equivalent, $\%$ & $<0.72$ \\
\hline
\end{tabular}

Table 2

Granulometric composition of aggregates

\begin{tabular}{l|c|c|c}
\hline \multirow{2}{*}{$\begin{array}{c}\text { Radius of the } \\
\text { sieve's mesh, mm }\end{array}$} & \multicolumn{3}{|c}{ The amount of poured out material, \% } \\
\cline { 2 - 4 } & $\begin{array}{c}\text { Sand fraction } \\
0 / 1\end{array}$ & $\begin{array}{c}\text { Sand fraction } \\
0 / 4\end{array}$ & $\begin{array}{c}\text { Gravel fraction } \\
4 / 16\end{array}$ \\
\hline 32.0 & - & - & 100.0 \\
\hline 16.0 & - & - & 95.6 \\
\hline 8.0 & 100.0 & 100.0 & 34.9 \\
\hline 4.0 & 100.0 & 97.8 & 2.9 \\
\hline 2.0 & 99.9 & 86.3 & 0.7 \\
\hline 1.0 & 94.8 & 68.5 & 0.7 \\
\hline 0.500 & 39.1 & 37.9 & 0.7 \\
\hline 0.250 & 3.0 & 4.9 & 0.7 \\
\hline 0.125 & 0.3 & 1.2 & 0.7 \\
\hline 0 & 0.2 & 0.1 & 0.1 \\
\hline
\end{tabular}

Portland cement CEM II/A-LL $42.5 \mathrm{R}$ (MA) (A) (JSC Akmenès cementas production) was used for the test. Physical, mechanical properties and chemical composition of Portland cement CEM II/ A-LL 42.5 $R$ are given in Table 1.

Washed sand from "Kvesu quarry" with the fractions of $0 / 1$ and $0 / 4$, bulk densities of $1521 \mathrm{~kg} / \mathrm{m}^{3}$ and $1711 \mathrm{~kg} / \mathrm{m}^{3}$ and fineness modules of 1.78 and 2.62 was used as fine aggregates. Gravel with the fraction of $4 / 16$ and bulk density of $1657 \mathrm{~kg} / \mathrm{m}^{3}$ was used as the coarse aggregate. Granulometric composition of aggregates is conducted according to EN 12620:2013 and presented in Table 2.

In this investigation, concrete admixtures were chosen, which are widely used in the concrete monolithic projects. Concrete mixtures were prepared by using combination of two different chemical admixtures, e.g. SP and AFA, SP and VMA, SP and AEA. The description of chemical admixture (BASF Construction Chemicals Italia Spa) used in this study is indicated in Table 3. The amount of concrete's admixture was calculated as \% of cement mass. 


\begin{tabular}{l|c|c|c|c}
\hline \multicolumn{1}{c|}{ Name } & Glenium SKY 628 & Rheomix 880 & Rheomatrix 100 & Micro Air G (LP) \\
\hline Admixture & Super-plasticizer & Anti-foaming & Viscosity modifying & Air-entraining \\
\hline Marking & SP & AFA & VMA & AEA \\
\hline Compound-based & Polycarboxylate & Propoxylate- etoxylate & Synthetic -copolymer & Modified -resin \\
\hline Recommended dosage, $\%$ & $0.6-1.4$ & $0.1-0.3$ & $0.1-1.5$ & $0-0.3$ \\
\hline Density, g/cm 3 & $1.06-1.10$ & $0.97 \pm 0.02$ & $1.00-1.02$ & $0.98-1.04$ \\
\hline Viscosity, mPaxS & - & $<600$ & - & - \\
\hline pH & - & - & $6-9$ & $9-11$ \\
\hline Chloride quantity, \% & $<0.1$ & - & $<0.1$ & $<0.01$ \\
\hline Alkali quantity, $\%$ & $<2.5$ & - & - & - \\
\hline
\end{tabular}

Table 3

Description of chemical admixture used for concrete mixture preparation

Table 4

Composition of concrete mixtures 
28 days with the temperature of $20 \pm 4^{\circ} \mathrm{C}$ and relative humidity of $60 \pm 2 \%$ (non-standard method). The density of hardened concrete was determined according to standard EN 12390-7:2009. The specimen was tested after curing in water; when 2-4 hours were passed after specimen was removed from water or it was taken from the curing room. The volume was calculated from the regular shape of the specimen size. The compressive strength of hardened concrete specimens was determined according to standard EN 12390-3:32009. Scale coefficient of specimens $100 \times 100 \times 100 \mathrm{~mm}$ a equal 0.95 . Specimens surface flatness and sides perpendicularity with noticed base satisfied standard EN 12390-1:2012 requirements.

Microsoft Excel program was used for identifying the best dependence of the dispersion of the density and comprehensive strength values of hardened concrete and equation's empirical coefficients values. Correlation coefficient (Pirson), which is evaluating the strength of linear relationship, was calculated according to coefficient of empirical equation. The closer correlation coefficient is to 1 , the better representation of the dispersion of values in the curve. According to the obtained correlation coefficient, it was determined which equation describes the best distribution of statistical data.

\section{Results}

\section{The influence of super-plasticizing admixture (SP) on concrete specimens' density and compressive strength under different curing conditions}

The dependence of density and compressive strength of hardened concrete (mixture's compositions BA4-0-BA4-6) from the amount of SP admixture in \% of cement mass, under different curing conditions is presented in Fig. $1 \mathrm{a}$ and $1 \mathrm{~b}$.

The Fig. 1a shows, that the trends of density of concrete specimens were similar even after curing them under different conditions. When the amount of SP admixture was increased from 0.6 to $1.8 \%$ of the cement mass, the average density of specimens cured by standard method was in the range of $2370 \div 2410 \mathrm{~kg} / \mathrm{m}^{3}$, and the average density of specimens cured by non-standard method was in the range of $2310 \div 2400 \mathrm{~kg} / \mathrm{m}^{3}$, then water and cement ratio was constant and equal to 0.54 . The same average density $\left(2400 \mathrm{~kg} / \mathrm{m}^{3}\right)$ of the specimens which were cured under different conditions was obtained with SP admixture of $1.4 \%$ of the cement mass. Then the amount of SP admixture was increased from 0.6 to $1.8 \%$ of the cement mass, the average density of specimens cured by standard method was increased by 1.02 times, and the average density of specimens cured by non-standard method was increased by 1.03 times.

When the amount of SP admixture was increased from 0.6 to $1.8 \%$ of the cement mass (Figure $1 \mathrm{~b}$ ), the average compressive strength of specimens cured by standard method was in the

Fig. 1

The hardened concrete density (a) and compressive strength (b) depending on the amount of SP

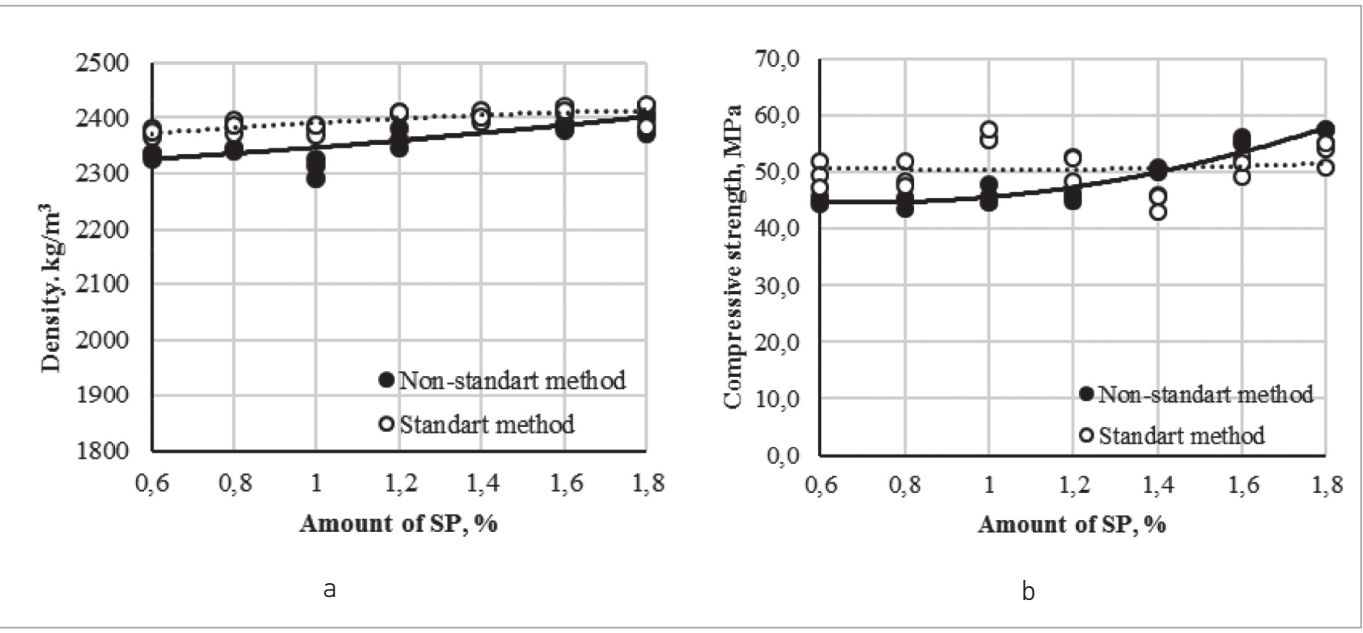


range of $49.6 \div 53.3 \mathrm{MPa}$, and the average compressive strength of specimens cured by non-standard method was in the range of $45.0 \div 56.7 \mathrm{MPa}$. Then the amount of SP admixture was exceeding $1.2 \%$ of the cement mass, the average compressive strength of specimens cured by non-standard method was 1.09 times higher then the average compressive strength of specimens cured by standard method. Then the amount of SP admixture was exceeding $1.4 \%$ of the cement mass, water separation from the mixture was observed, which could have influenced the compressive strength of concrete specimens.

\begin{tabular}{|c|c|c|c|c|c|c|c|c|}
\hline \multirow{2}{*}{$\begin{array}{l}\text { Curing } \\
\text { method }\end{array}$} & \multirow{2}{*}{$\begin{array}{l}\text { Properties } \\
\text { of hardened } \\
\text { concrete }\end{array}$} & \multirow[t]{2}{*}{ Equation } & \multicolumn{3}{|c|}{$\begin{array}{c}\text { Coefficients value of } \\
\text { equation }\end{array}$} & \multirow{2}{*}{$\begin{array}{l}R \text {-squared } \\
\quad \text { value }\end{array}$} & \multirow{2}{*}{$\begin{array}{c}\text { Correlation } \\
\text { coefficient } \\
r\end{array}$} & \multirow{2}{*}{$\begin{array}{c}\text { Connection } \\
\text { between } \\
\text { variables }\end{array}$} \\
\hline & & & $a$ & $b$ & c & & & \\
\hline \multirow{2}{*}{$\begin{array}{l}\text { Non- } \\
\text { standart }\end{array}$} & Density & $y=a \cdot x^{2}+b \cdot x+c$ & 12,22 & 34,00 & 2301,0 & 0,587 & 0,76 & strong \\
\hline & $\begin{array}{l}\text { Compres. } \\
\text { strength }\end{array}$ & $y=a \cdot x^{2}-b \cdot x+c$ & 11,15 & 15,81 & 50,26 & 0,914 & 0,96 & strong \\
\hline \multirow{2}{*}{ Standart } & Density & $y=-a \cdot x^{2}+b \cdot x+c$ & 17,64 & 76,54 & 2332,4 & 0,596 & 0,77 & strong \\
\hline & $\begin{array}{l}\text { Compres. } \\
\text { strength }\end{array}$ & $y=a \cdot x^{2}-b \cdot x+c$ & 1,91 & 3,97 & 52,50 & 0,010 & 0,10 & very weak \\
\hline
\end{tabular}

From Table 5 we can see, that values of dispersion of dependence of hardened concrete density and compressive strength on amount of SP admixture under different curing conditions can be described by polynomial dependencies. The values of correlation coefficient were in the range from 0.10 till 0.96 .

\section{The influence of anti-foaming admixture (AFA) on concrete specimens' density and compressive strength under different curing conditions}

The dependence of density and compressive strength of hardened concrete (mixture's compositions BA5-0-BA5-6) from the amount of AFA admixture in \% of cement mass, under different curing conditions is presented in Fig. $2 a$ and $2 b$. From Fig. $2 a$ we can see, that the trends of density of concrete specimens were similar even after curing them under different conditions. When the amount of AFA admixture was increased from 0 to $0.3 \%$ of the cement mass, the average density of specimens cured by standard method was in the range of $2400 \div 2420 \mathrm{~kg} / \mathrm{m}^{3}$, and the average density of specimens cured by non-standard method was in the range of $2350 \div 2400 \mathrm{~kg} / \mathrm{m}^{3}$. It was observed, that the density of specimens cured by standard method was 1.02 times higher then the density of specimens cured by non-standard method. When the amount of AFA admixture was increased from 0 to $0.3 \%$ of the cement mass, the average density of specimens cured by standard method was increased from $2400 \mathrm{~kg} / \mathrm{m}^{3}$ till $2410 \mathrm{~kg} / \mathrm{m}^{3}$, and the average density of specimens cured by non-standard method was decreased from $2400 \mathrm{~kg} / \mathrm{m}^{3}$ till $2360 \mathrm{~kg} / \mathrm{m}^{3}$. The amount of SP admixture was constant and equal to $1.4 \%$ of the cement mass. According to author (Lazniewska-Piekarczyka, 2013) the effects of modification by AFA of high performance self-compacting concrete (HPSCC) depend on their type very significantly. The type of AFA impacts very significantly on the air content of HPSCC. In case of one AFA type, it is significant increase in diameter of flow while reducing the air content in HPSCC. Other type of AFA does not improve the workability and does not cause a significant reduction in the air content in HPSCC. The type of AFA is also important because of the parameters values of the air voids of HPSCC. Depending on the type of AFA, the change of the size and content of pores in HPSCC differs.

The Fig. $2 b$ shows, that the trends of compressive strength of concrete specimens, cured under different conditions, depended on the amount of admixture in \% of cement mass. When the amount of AFA admixture was $0.05 \%$ of the cement mass, the average compressive strength

\section{Table 5}

The dependence of dispersion of data 
Fig. 2

The hardened concrete density (a) and compressive strength

(b) depending on the amount of AFA

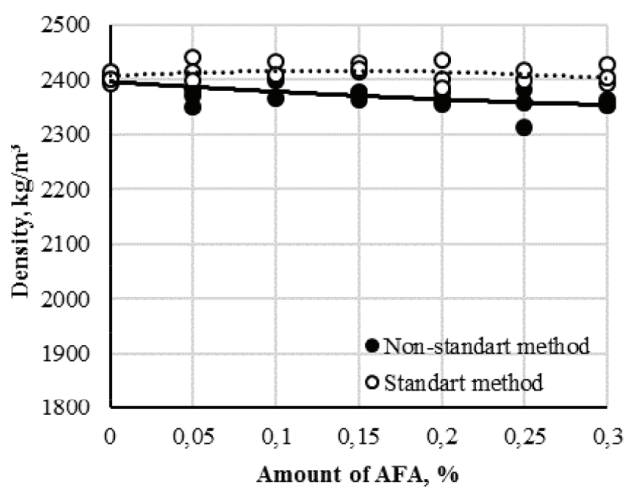

a

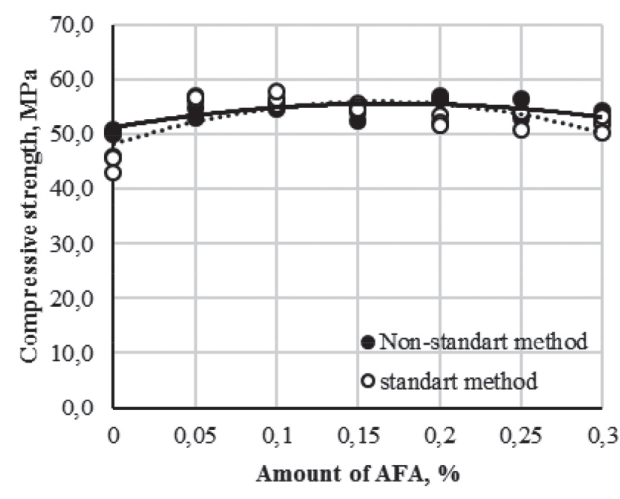

b

of specimens cured by standard method was 1.26 times higher, and the average compressive strength of specimens cured by non-standard method was 1.08 times higher, compared with a control specimen without AFA admixture. When the amount of AFA admixture was increased to $0.3 \%$ of the cement mass, the average compressive strength of specimens cured by standard method was 1.09 times lower, and the average compressive strength of specimens cured by non-standard method was 1.03 times lower. Then the amount of AFA admixture was exceeding $0.15 \%$ of the cement mass, the average compressive strength of specimens cured by non-standard method was 1.04 times higher then the average compressive strength of specimens cured by standard method. When the amount of AFA admixture was increased from 0.05 to $0.3 \%$ of the cement mass, the average compressive strength of specimens cured by standard method was in the range of $56.7 \div 51.9 \mathrm{MPa}$, and the average compressive strength of specimens cured by non-standard method was in the range of $54.8 \div 53.2 \mathrm{MPa}$. The most rational amount of AFA admixture (for the analysed mixture) could be $0.15 \%$ of the cement mass, when compressive strength of specimens cured by standard method is considered.

Table 6

The dependence of dispersion of data

\begin{tabular}{|c|c|c|c|c|c|c|c|c|}
\hline \multirow{2}{*}{$\begin{array}{l}\text { Curing } \\
\text { method }\end{array}$} & \multirow{2}{*}{$\begin{array}{l}\text { Properties } \\
\text { of hardened } \\
\text { concrete }\end{array}$} & \multirow[t]{2}{*}{ Equation } & \multicolumn{3}{|c|}{$\begin{array}{l}\text { Coefficients value of } \\
\text { equation }\end{array}$} & \multirow{2}{*}{$\begin{array}{l}R \text {-squared } \\
\text { value }\end{array}$} & \multirow{2}{*}{$\begin{array}{c}\text { Correlation } \\
\text { coefficient } \\
r\end{array}$} & \multirow{2}{*}{$\begin{array}{c}\text { Connection } \\
\text { between } \\
\text { variables }\end{array}$} \\
\hline & & & $a$ & $b$ & c & & & \\
\hline \multirow{2}{*}{$\begin{array}{l}\text { Non- } \\
\text { standart }\end{array}$} & Density & $y=a \cdot x^{2}-b \cdot x+c$ & 198,38 & 199,33 & 2396,3 & 0,406 & 0,64 & quiet \\
\hline & $\begin{array}{l}\text { Compres. } \\
\text { strength }\end{array}$ & $y=-a \cdot x^{2}+b \cdot x+c$ & 153,31 & 52,25 & 51,19 & 0,516 & 0,72 & strong \\
\hline \multirow[b]{2}{*}{ Standart } & Density & $y=-a \cdot x^{2}+b \cdot x+c$ & 486,43 & 132,34 & 2407,2 & 0,086 & 0,29 & weak \\
\hline & $\begin{array}{l}\text { Compres. } \\
\text { strength }\end{array}$ & $y=-a \cdot x^{2}+b \cdot x+c$ & 301,14 & 97,08 & 48,14 & 0,479 & 0,69 & quiet \\
\hline
\end{tabular}

From Table 6 we can see, that values of dispersion of dependence of hardened concrete density and compressive strength on amount of AFA admixture under different curing conditions can be described by polynomial dependencies. The values of correlation coefficient were in the range from 0.29 till 0.72 .

\section{The influence of viscosity modifying admixture (VMA) on concrete specimens' den- sity and compressive strength under different curing conditions}

The dependence of density and compressive strength of hardened concrete (mixture's compositions BA6-0-BA6-6) from the amount of VMA admixture in \% of cement mass, under different curing conditions is presented in Fig. $3 a$ and $3 b$. 


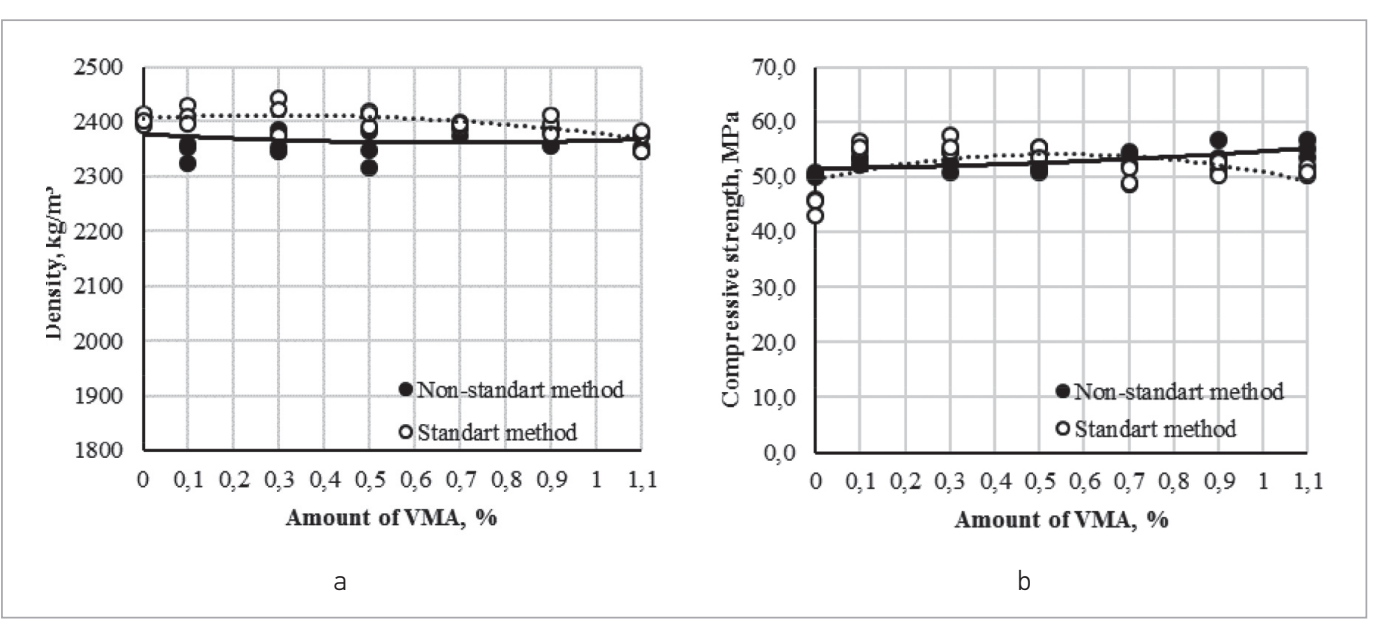

The Fig. 3a shows, that the trends of density of concrete specimens were not analogical after curing them under different conditions. When the amount of VMA admixture was increased from 0 to $1.1 \%$ of the cement mass, the average density of specimens cured by standard method was in the range of $2370 \div 2410 \mathrm{~kg} / \mathrm{m}^{3}$, and the average density of specimens cured by non-standard method was in the range of $2350 \div 2400 \mathrm{~kg} / \mathrm{m}^{3}$. The amount of SP admixture was constant $(1.4 \%$ of the cement mass). When the amount of VMA admixture was increased from 0.1 to $1.1 \%$ of the cement mass, the average density of specimens cured by standard method was decreased from $2410 \mathrm{~kg} / \mathrm{m}^{3}$ till $2370 \mathrm{~kg} / \mathrm{m}^{3}$. The average density of specimens cured by non-standard method, with CA3 admixture from $0.1 \div 0.5 \%$ of the cement mass, was decreased from $2400 \mathrm{~kg} / \mathrm{m}^{3}$ till $2350 \mathrm{~kg} / \mathrm{m}^{3}$. When the amount of VMA admixture was increased till $1.1 \%$ of the cement mass, the average density of specimens cured by non-standard method was increased from $2350 \mathrm{~kg} / \mathrm{m}^{3}$ till $2360 \mathrm{~kg} / \mathrm{m}^{3}$. The same average density $\left(2390 \mathrm{~kg} / \mathrm{m}^{3}\right)$ of specimens, cured by different conditions, was obtained with VMA admixture of $0.7 \%$ of the cement mass. According to author (Lazniewska-Piekarczyka, 2013) VMA, depending on the type of AFA and VMA, has more or less beneficial effect on the air content in HPSCC. The use of one type of VMA does not increase the air content in HPSCC with AFA. Another type of VMA significantly increases the air content in HPSCC with AFA. VMA affects the air content in HPSCC, also depends on the type of AFA. Depending on the type of VMA and AFA, a very different change in the characteristics of the air voids is observed. In one case, VMA does not change the characteristics of the porosity, in the second, significantly affects.

The Fig. $3 b$ shows, that the trends of compressive strength of concrete specimens, cured under different conditions were not identical. When the amount of VMA admixture was $0.1 \%$ of the cement mass, the average compressive strength of specimens cured by standard method was 1.24 times higher, and the average compressive strength of specimens cured by non-standard method was 1.05 times higher, compared with a control specimen without VMA admixture. When the amount of VMA admixture was increased from 0.1 to $0.5 \%$ of the cement mass, the average compressive strength of specimens cured by standard and non-standard methods were slightly lower, respectively from 55.6 MPa till 54.7 MPa and from 53.0 MPa till 51.2 MPa. When the amount of VMA admixture was increased from 0.5 to $1.1 \%$ of the cement mass, the average compressive strength of specimens cured by standard method was decreased from 54.7 MPa till 51.4 MPa, and the average compressive strength of specimens cured by non-standard method was increased from 51.2 MPa till 55.2 MPa. Then the amount of VMA admixture was exceeding $0.6 \%$ of the cement mass, the average compressive strength of specimens cured by non-standard method was 1.07 times higher than the average compressive strength of specimens cured by standard method. The most rational amount of CA3 admixture (for the analysed mixture) could be $0.5 \%$ of the cement mass, when compressive strength of specimens cured by standard method is considered.
Fig. 3

The hardened concrete density (a) and compressive strength (b) depending on the amount of VMA 
Table 7

The dependence of dispersion of data

\begin{tabular}{|c|c|c|c|c|c|c|c|c|}
\hline \multirow{2}{*}{$\begin{array}{l}\text { Curing } \\
\text { method }\end{array}$} & \multirow{2}{*}{$\begin{array}{l}\text { Properties } \\
\text { of hardened } \\
\text { concrete }\end{array}$} & \multirow{2}{*}{ Equation } & \multicolumn{3}{|c|}{$\begin{array}{c}\text { Coefficients value of } \\
\text { equation }\end{array}$} & \multirow{2}{*}{$\begin{array}{l}R \text {-squared } \\
\text { value }\end{array}$} & \multirow{2}{*}{$\begin{array}{c}\text { Correlation } \\
\text { coefficient } \\
r\end{array}$} & \multirow{2}{*}{$\begin{array}{c}\text { Connection } \\
\text { between } \\
\text { variables }\end{array}$} \\
\hline & & & $a$ & $b$ & $c$ & & & \\
\hline \multirow{2}{*}{$\begin{array}{l}\text { Non- } \\
\text { standart }\end{array}$} & Density & $y=a \cdot x^{2}-b \cdot x+c$ & 34,30 & 46,32 & 2377,0 & 0,046 & 0,21 & weak \\
\hline & $\begin{array}{l}\text { Compres. } \\
\text { strength }\end{array}$ & $y=a \cdot x^{2}+b \cdot x+c$ & 2,325 & 0,821 & 51,51 & 0,448 & 0,67 & quiet \\
\hline \multirow{2}{*}{ Standart } & Density & $y=-a \cdot x^{2}+b \cdot x+c$ & 63,67 & 36,41 & 2406,1 & 0,432 & 0,66 & quiet \\
\hline & $\begin{array}{l}\text { Compres. } \\
\text { strength }\end{array}$ & $y=-a \cdot x^{2}+b \cdot x+c$ & 15,57 & 16,89 & 49,55 & 0,230 & 0,48 & weak \\
\hline
\end{tabular}

From Table 7 we can see, that values of dispersion of dependence of hardened concrete density and compressive strength on amount of VMA admixture under different curing conditions can be described by polynomial dependencies. The values of correlation coefficient were in the range from 0.21 till 0.67 .

\section{The influence of air-entraining admixture (AEA) on concrete specimens' density and compressive strength under different curing conditions}

The dependence of density and compressive strength of hardened concrete (mixture's compositions BA7-0-BA7-6) from the amount of AEA admixture in \% of cement mass, under different curing conditions is presented in Fig. $4 \mathrm{a}$ and $4 \mathrm{~b}$.

Fig. 4

The hardened concrete density (a) and compressive strength (b) depending on the amount of AEA
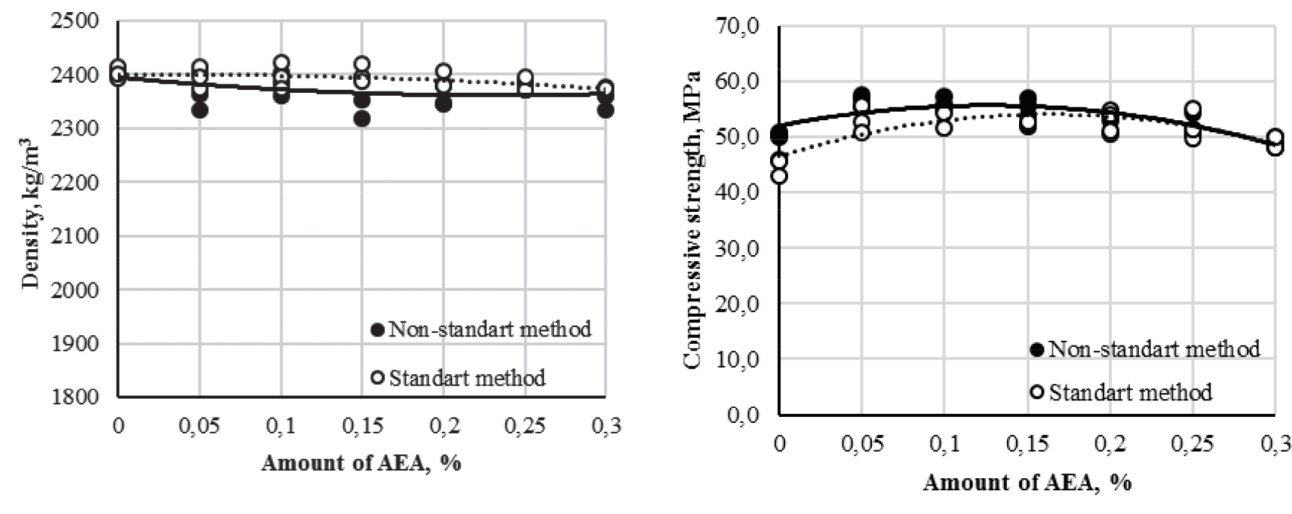

b

From Fig. $4 a$ we can see, that the trends of density of concrete specimens were similar after curing them under different conditions. When the amount of AEA admixture was increased from 0 to $0.3 \%$ of the cement mass, the average density of specimens cured by standard method was decreased from $2400 \mathrm{~kg} / \mathrm{m}^{3}$ till $2380 \mathrm{~kg} / \mathrm{m}^{3}$. The average density of specimens cured by non-standard method was decreased from $2400 \mathrm{~kg} / \mathrm{m}^{3}$ till $2350 \mathrm{~kg} / \mathrm{m}^{3}$. The amount of SP admixture was constant $(1.4 \%$ of the cement mass). It was observed, that when the amount of AEA admixture was increased from 0.05 to $0.3 \%$ of the cement mass, the average density of specimens cured by standard method was 1.01 times higher compared with average density of specimens cured by non-standard method.

The Fig. $4 \mathrm{~b}$ shows, that the trends of compressive strength of concrete specimens, cured under different conditions were similar. Air-entraining admixture, taking into account it's intended use, is increasing porosity of hardened concrete and decreasing it's density. When the amount of AEA 
admixture was $0.05 \%$ of the cement mass, the average compressive strength of specimens cured by standard method was 1.18 times higher, and the average compressive strength of specimens cured by non-standard method was 1.12 times higher, compared with a control specimen without AEA admixture. When the amount of AFA admixture was increased to $0.25 \%$ of the cement mass, the average compressive strength of specimens cured by non-standard method was almost the same as the average compressive strength of specimens cured by standard method. When the amount of AEA admixture was increased from 0.05 to $0.15 \%$ of the cement mass, the average compressive strength of specimens cured by standard and non-standard methods was decreasing, respectively from 53.1 MPa till 52.2 MPa and from 56.6 MPa till 55.4 MPa. It was observed, that the average compressive strength of specimens cured by non-standard method was 1.06 times higher than the average compressive strength of specimens cured by standard method. When the amount of AEA admixture exceeded $0.2 \%$ of the cement mass, the average compressive strength of specimens cured by standard method was higher then the average compressive strength of specimens cured by non-standard method.

\begin{tabular}{|c|c|c|c|c|c|c|c|c|}
\hline \multirow{2}{*}{$\begin{array}{l}\text { Curing } \\
\text { method }\end{array}$} & \multirow{2}{*}{$\begin{array}{c}\text { Properties } \\
\text { of hardened } \\
\text { concrete }\end{array}$} & \multirow{2}{*}{ Equation } & \multicolumn{3}{|c|}{$\begin{array}{c}\text { Coefficients value of } \\
\text { equation }\end{array}$} & \multirow{2}{*}{$\begin{array}{l}R \text {-squared } \\
\text { value }\end{array}$} & \multirow{2}{*}{$\begin{array}{c}\text { Correlation } \\
\text { coefficient } \\
r\end{array}$} & \multirow{2}{*}{$\begin{array}{c}\text { Connection } \\
\text { between } \\
\text { variables }\end{array}$} \\
\hline & & & $a$ & $b$ & c & & & \\
\hline \multirow{2}{*}{$\begin{array}{l}\text { Non- } \\
\text { standart }\end{array}$} & Density & $y=a \cdot x^{2}-b \cdot x+c$ & 612,7 & 284,5 & 2394,1 & 0,195 & 0,44 & weak \\
\hline & $\begin{array}{l}\text { Compres. } \\
\text { strength }\end{array}$ & $y=-a \cdot x^{2}+b \cdot x+c$ & 235,0 & 59,05 & 51,98 & 0,648 & 0,80 & strong \\
\hline \multirow{2}{*}{ Standart } & Density & $y=-a \cdot x^{2}+b \cdot x+c$ & 334,3 & 11,84 & 2400,4 & 0,320 & 0,57 & quiet \\
\hline & $\begin{array}{l}\text { Compres. } \\
\text { strength }\end{array}$ & $y=-a \cdot x^{2}+b \cdot x+c$ & 284,8 & 92,95 & 46,50 & 0,609 & 0,78 & strong \\
\hline
\end{tabular}

From Table 8 we can see, that values of dispersion of dependence of hardened concrete density and compressive strength on amount of AFA admixture under different curing conditions can be described by polynomial dependencies. The values of correlation coefficient were in the range from 0.44 till 0.80 .

The results obtained showed that the specimens without air-entraining admixture show a deterioration of mechanical properties after the freeze-thaw test (Łazniewska-Piekarczyk ${ }^{b}, 2013$ ). However, the inclusion of air bubbles benefits the behaviour of concrete against freeze-thaw cycles so even better mechanical properties after the test were observed. This anomalous behaviour is because the cement hydration process continues over the freeze-thaw tests, closing the pore structure. This aspect has been confirmed with the DTA and TG tests performed.

1 Regardless of the type of the chemical admixture, which was used to modify concrete mixture, the 28-day density of specimens cured by standard method (in water at the temperature of $20 \pm 2^{\circ} \mathrm{C}$ ) was higher by several \% comparing with the 28-day density of specimens cured by non-standard method (in a room with the temperature of $20 \pm 4^{\circ} \mathrm{C}$ and relative humidity of $60 \pm 2 \%)$.

The tendencies of 28-day compressive strength of concrete specimens cured by standard and non-standard methods depended on the type and percentage of the chemical admixture:

when the amount of SP admixture exceeded $1.2 \%$ of the cement mass, the average compressive strength of specimens cured by non-standard method was $1.09 \%$ higher than the average compressive strength of specimens cured by standard method;
Table 8

The dependence of dispersion of data 
when the amount of AFA admixture exceeded $0.15 \%$ of the cement mass, the average compressive strength was $1.04 \%$ higher;

- when the amount of VMA admixture exceeded $0.6 \%$ of the cement mass, the average compressive strength was $1.07 \%$ higher;

when the amount of AEA admixture reached $0.25 \%$ of the cement mass, the average compressive strength of specimens cured by non-standard method was almost equal to the average compressive strength of specimens cured by standard method.

3 According to the obtained correlation coefficient, it was determined that polynomial equation describes the best distribution of statistical data. The dependence of hardened concrete density and compressive strength on type and percentage of chemical admixtures under different curing conditions can be described by polynomial dependencies.

Density of concrete specimens with different type and amount of chemical admixtures 4 cured by non-standard method correlation coefficients were in the range from 0.21 till 0.76 and density of concrete specimens cured by standard method - from 0.29 till 0.77 .

5 Compressive strength of concrete specimens with different type and amount of chemical admixtures cured by non-standard method correlation coefficients were in the range from 0.67 till 0.96 and compressive strength of concrete specimens cured by standard method - from 0.48 till 0.80 .

\section{References}

Al-Assadi G., Casati M.J., Fernandez J., Galvez J.C. Effect of the curing conditions of concrete on the behaviour under freeze-thaw cycles, Fatigue \& Fracture of Engineering Materials \& Structures, 2010; 34: 461-470. http://dx.doi.org/10.1111/j.14602695.2010.01520.x

Albayraka G., Canbaza M., Albayraka U. Statistical analysis of chemical admixtures usage for concrete: A survey of Eskisehir city, Turkey, Procedia Engineering, 2015; 118: 1236-1241. http://dx.doi. org/10.1016/j.proeng.2015.08.475

Ali M.-A., Murat T., Gokhan Y., Omer A., Kambiz R. Effect of different types of superplasticizer on fresh, rheological and strength properties of self-consolidating concrete, Construction and Building Materials, 2013; 47: 1020-1025. http://dx.doi. org/10.1016/j.conbuildmat.2013.05.105

Atis C.D. Strength properties of high-volume fly ash roller compacted and workable concrete and influence of curing condition, Cement and Concrete Research, 2005; 35: 1112-1121. http://dx.doi. org/10.1016/j.cemconres.2004.07.037

Atis C.D., Ozcan F., Kılıc A., Karahan O., Bilim C., Severcan M.H. Influence of dryand wet curing conditions on compressive strength of silica fume concrete, Building and Environment, 2005; 40: 1678-1683. http://dx.doi.org/10.1016/j.buildenv.2004.12.005
Gayarre F.L., Cabo A.D., Pérez C.L.-C., López M. A. S. The effect of curing conditions on the compressive strength of recycled aggregate concrete, Construction and Building Materials, 2014; 53: 260-266. http://dx.doi.org/10.1016/j.conbuildmat.2013.11.112

Khatib J.M., Mangat P.S. Influence of superplasticizer and curing on porosity and pore structure of cement paste. Cement and Concrete Composites, 1999; 21: 431-437. http://dx.doi.org/10.1016/ S0958-9465(99)00031-1

Łazniewska-Piekarczyk $k^{b}$ B. The influence of admixtures type on the air-voids parameters of nonair-entrained and air-entrained high performance SCC, Construction and Building Materials, 2013; 41: 109-124. http://dx.doi.org/10.1016/j.conbuildmat.2012.11.086

Lazniewska-Piekarczyk ${ }^{a}$ B. The influence of chemical admixtures on cement hydration and mixture properties of very high performance self-compacting concrete, Construction and Building Materials, 2013; 49: 643-662. http://dx.doi.org/10.1016/j.conbuildmat.2013.07.072

Ling I.H., Teo D.C.L. Properties of EPS RHA lightweight concrete bricks under different curing conditions, Construction and Building Materials, 2011; 25: 3648-3655. http://dx.doi.org/10.1016/j.conbuildmat.2011.03.061 
Ling T.-Ch., Poon Ch.-S., Kou Sh.-C. Influence of recycled glass content and curing conditions on the properties of self-compacting concrete after exposure to elevated temperatures, Cement and Concrete Composites, 2012; 34: 265-272. http://dx.doi. org/10.1016/j.cemconcomp.2011.08.010

Plank J., Sakai E., Miao C.W., Yud C., Hong J.X. Chemical admixtures - Chemistry, applications and their impact on concrete microstructure and durability, Cement and Concrete Research, 2015; 78: 81-99. http://dx.doi.org/10.1016/j.cemconres.2015.05.016 Saric-Coric M., Khayat K.H., Tagnit-Hamou A. Performance characteristics of cement grouts made with various combinations of high-range water reducer and cellulose-based viscosity modifier, Cement and Concrete Research, 2003; 33: 1999-2008.
http://dx.doi.org/10.1016/S0008-8846(03)00214-X

Tan K., Gjorv O. E. Performance of concrete under different curing conditions, Cement and Concrete Research, 1996; 26: 355-361. http://dx.doi. org/10.1016/S0008-8846(96)85023-X

Turkmen I. Influence of different curing conditions on the physical and mechanical properties of concretes with admixtures of silica fume and blast furnace slag, Materials Letters, 2003; 57: 4560-4569. http://dx.doi.org/10.1016/S0167-577X(03)00362-8

Zhao H., Sun W., Wu X., Gao B. Effect of initial water-curing period and curing condition on the properties of self-compacting concrete, Materials and Design, 2012; 35: 194-200. http://dx.doi. org/10.1016/j.matdes.2011.09.053

\section{GINTAS \\ BRAZAS}

Position at the organization

Master at Faculty

of Civil Engineering

and Architecture,

Department of

Construction

Technologies

Main research area

Civil engineering

\section{Address}

Studentu str. 48, LT-51367 Kaunas,

Lithuania

Tel. +370 37300479

E-mail: gintas@gmail. com

\section{MINDAUGAS DAUKŠYS \\ Position at the organization}

Dr. at Faculty of

Civil Engineering

and Architecture,

Department of

Construction

Technologies

Main research area

Civil engineering, construction technology

\section{Address}

Studentu str. 48,

LT-51367 Kaunas,

Lithuania

Tel. +370 37300479

E-mail: mindaugas. dauksys@ktu.lt

\section{ALBERTAS KLOVAS}

Position at the organization

Ph.D student at Faculty of Civil Engineering and Architecture, Department of Construction

Technologies

Main research area

Civil engineering, construction technology

\section{Address}

Studentu str. 48, LT-51367 Kaunas, Lithuania Tel. +370 37300479

E-mail: albertas. klovas@ktu.lt
JOLANTA ŠADAUSKIENE்

Position at the organization

Dr. at Faculty of Civil Engineering and Architecture, Department of Building Energy Systems

\section{Main research area}

Civil engineering

\section{Address}

Studentu str. 48, LT-51367 Kaunas,

Lithuania

Tel. +370 37300492

E-mail: jolanta. sadauskiene@ktu.lt

\section{About the authors}

